\title{
Marta Rossetti Batista: \\ amiga, colega e diretora
}

Lucy Maffei Hutter ${ }^{1}$

Marta, colega e amiga, sempre benquista por todos do Instituto de Estudos Brasileiros, desempenhou, durante os anos que permaneceu na Instituição, um excelente trabalho como pesquisadora e docente da área de Artes Plásticas.

Sempre entusiasmada com os modernistas estudou com afinco Tarsila do Amaral, Brecheret, entre outros. Sua obra mais recente é a editada em 2006 pelas Editoras 34 e EDUSP: Anita Malfatti no tempo e no espaço: biografia e estudo da obra. Tratase de um trabalho de fôlego, em dois volumes, sendo o segundo o Catálogo das obras de Anita.

Como diretora do Instituto, ampliou a rede de informática nos vários setores e voltou sua atenção para a área de pesquisa e docência.

Coordenou, no Brasil, o Projeto de Cooperação CAPES/ COFECUB, tendo o Instituto de Estudos Brasileiros sediado a coordenação brasileira e, na França, o Institut des Hautes Études de L'Amérique Latine respondido pela coordenação francesa. Consistiu o projeto numa pesquisa realizada por professores brasileiros e franceses, cuja equipe tive oportunidade de fazer parte. Tal projeto financiado pela CAPES, no Brasil, e pelo COFECUB, na França, teve como objeto de análise a "História comparada de sociedades urbanas: políticas urbanas e dimensão cultural de cidades brasileiras e francesas (1840-1945)".

0 projeto desenvolveu-se de 1995 a 1998. Alguns dos resultados iniciais foram apresentados no Congresso Internacional de Americanistas, do qual participamos, ocorrido em Quito (Equador) no mês de julho de 1997.

No Brasil, os estudos abrangeram várias cidades além de São Paulo: Rio de Janeiro, Porto Alegre, Curitiba, Recife e Salvador. Os enfoques sobre o tema geral foram diversificados: o cotidiano urbano, a cidade e o imigrante, bem como as artes em São Paulo; urbanização em Curitiba; políticas públicas em Recife; mudanças das estruturas demográficas e urbanas em Curitiba; Porto Alegre na historiografia; aspectos urbanos e

1 Docente do IEB (área de História). 
sociais no Rio de Janeiro; a mudança do desenho urbano e as reformas na cidade de Salvador, afora outros estudos.

Os temas acima referidos - aliás indicados no próprio título do projeto - foram, igualmente, analisados pelos professores franceses a ele ligados.

Estamos mencionando o Projeto de Cooperação CAPES/ COFECUB História comparada de sociedades urbanas: politicas urbanas e dimensão cultural de cidades brasileiras e francesas (1840-1945), porque a Marta não só coordenou os trabalhos referentes ao Brasil, como Diretora do Instituto de Estudos Brasileiros, mas, teve esse projeto, segundo nos parece, como uma das principais atuações de sua gestão.

Afora a coordenação, dedicou-se ela, no projeto, ao estudo de um tema relevante no contexto do desenvolvimento urbano: São Paulo e a arte nos espaços públicos: 1900-1925.

Dá, inicialmente, um resumo do rápido crescimento da cidade de São Paulo, nas décadas finais do século XIX, resultante da expansão da cultura cafeeira e da exportação do produto em larga escala; da implantação das ferrovias, da imigração em massa, entre outros fatores.

Os fazendeiros de café ligados à comercialização do produto e às finanças começam a construir casas em São Paulo. 0 comércio se desenvolvendo e a indústria em sua fase nascente atraem trabalhadores diversos. A população aumenta e, também, vão ocorrendo mudanças na urbanização.

Nesse contexto, Marta analisa a constituição dos primeiros museus e a atuação das escolas de Belas Artes. Cita a Coleção Sertório como base inicial do Museu Paulista, cuja inauguração ocorreu em 1895; a Pinacoteca do Estado que começou numa sala do Liceu de Artes e Ofícios, em princípios do século XX.

Chama a atenção para o fato de em São Paulo o Liceu de Artes e Ofícios suprir, então, a lacuna da não existência na cidade de uma escola de Belas Artes (antes Academia Imperial) como existia no Rio de Janeiro.

Segundo a autora

o Liceu de Artes e Ofícios tornou-se, na verdade, o único centro congregador dos artistas no início do século, contando com a presença de desenhistas, pintores, escultores, engenheiros e arquitetos, fornecendo abrigo a artistas visitantes.

Nesse trabalho Marta delineia a arte nas igrejas. Várias delas foram sendo construídas nos finais do século XIX e princípios do XX, entre elas a Igreja de Santa Cecília e a de Santa Efigênia. Já a Igreja da Consolação e o Mosteiro de São Bento passaram por uma reconstrução, além de iniciar-se o erguimento da nova Catedral. 
Destaca ela o Mosteiro de São Bento em sua nova edificação como uma obra "quase inteiramente importada": o projeto, os materiais e a arte sacra contaram com artistas alemães e belgas, o que não ocorreu com a nova Catedral, em cuja construção, embora em parte, tanto os projetos como o material e a mão-de-obra foram conseguidos na própria cidade de São Paulo.

Referindo-se às edificações dos finais do século XIX, definidas como estilo neoclássico, cita algumas delas, entre as quais a Escola Normal Caetano de Campos e a Escola Politécnica.

Já considerando as primeiras décadas do século XX, a autora destaca a construção do Teatro Municipal e o Palácio das Indústrias, o qual, segundo ela, foi um “delírio eclético”. Entre os estilos desse período relembra o art-nouveau e o neocolonial.

As esculturas dessa época também são delineadas: o Monumento a Giuseppe Garibaldi (colocado no Jardim da Luz), contribuição dos italianos de São Paulo; o Monumento à fundação de São Paulo (fundido na Itália); o Monumento a Carlos Gomes, entre outros.

São, ainda, focalizados monumentos construídos por ocasião do centenário da Independência do Brasil, tendo sido considerado como o de maior destaque o Monumento da Independência, posicionado em frente ao Museu Paulista.

Além desse trabalho, da coordenação brasileira, sediada no Instituto de Estudos Brasileiros, no final do Projeto CAPES/ COFECUB, a Marta ainda empenhou-se na publicação dos estudos elaborados pelos professores dos vários estados do Brasil que participaram do referido projeto.

Foram editados dois volumes: Cidades Brasileiras, Políticas urbanas e dimensão cultural e Cidades Brasileiras II. Politicas urbanas e dimensão cultural publicados, respectivamente, em 1998 e 1999.

Procuramos, nessa homenagem à Marta, nos determos no Projeto de Cooperação CAPES/COFECUB por julgarmos esse Projeto, como já acima mencionado, ter sido um dos compromissos de destaque da atuação da Marta como Diretora do Instituto.

Por outro lado, nos detivemos focalizando o seu trabalho São Paulo e a arte nos espaços públicos: 1900-1925 porque, a nosso ver, deve-se lembrar da Marta como atuante na Coleção do IEB e sempre empolgada com a pesquisa. Essa é a Marta que retemos em nossa memória e julgamos que ela concordaria plenamente com tal consideração. 